\title{
Assessment of urban land expansion using remote sensing and GIS: A case of Shiraz city, Iran
}

\author{
Abdulmannan Rouhani ${ }^{a},{ }^{*}$, Mohammadreza Elmi ${ }^{b}$ \\ ${ }^{a}$ Graduate of Department of Environmental Science, Yazd University, Yazd, Iran \\ ${ }^{b}$ Assistant professor, School of Natural Resources and Desert Studies, Department of Environmental Science, Yazd University, \\ Yazd, Iran
}

\section{Keywords}

Satellite Imagery; Remote Sensing;

Land Use; Shiraz City;

Landsat Images

\begin{abstract}
Urbanization and urban development is undoubtedly one of the most crucial aspects of modern civilization, causing various changes in the environment. Shiraz an area identified for rapid urban growth is less explored in the matter of study. In this context, this study presents a combined approach of remote sensing and GIS techniques for monitoring land use changes of Shiraz city in Fars Province, Iran. Firstly, various satellite images, including MSS 1982, TM 1996, ETM 2006, and OLI 2018 based on five classes, namely agriculture, urban areas, bare land, tree cover and street were classified. For classify the remote-sensing data maximum likelihood algorithm was used. Then, digital topographic maps 1:50000 of Geographic Organization of the Armed Forces and Mapping Organization were used as ancillary data for interpreting the images, also for geometric correction of the images. In the final phase of the study, the extent and status of changes in each application were determined, and the trends of changes were investigated. The results indicate a significant change in land use in regard to expansion of an urban area from $17.30 \%$ (1982) to $46.40 \%$ (2006) and 47.8\% (2018) by encroaching into agricultural and bare lands. Over this period, urban area has expanded by $624 \mathrm{Ha}$ per year on the average while this increase has been 238 $\mathrm{Ha}$ per year for the period 1996-2006. Moreover, during the first period, $198 \mathrm{Ha}$ of agricultural land has been degraded annually while this rate was 14 and $19 \mathrm{Ha}$ for the second and third periods, respectively, showing, increasing and declining trends in cover and application of the land over the three periods within the study area. The results of this research can be utilized as essential data to strengthen the effectiveness of the later urban planning of Shiraz City.
\end{abstract}

\section{Introduction}

The critical drivers of global environmental change are land use/cover changes [1]. The most important drivers of city growth and expansion that have been identified are: economic development, natural growth of population and migration from rural areas to cities [2]. Urban areas supply numerous human and physical resources, and urban expansion-related issues are also harsher in developing countries compared with developed ones [3]. Some of this issues by being recognized at the initial stages can be handled and some of them are permanent [3,4]. Consequently, investigate concentrated on cities in Asia is a timely, crucial task. Changes in land use/land cover able to modify the supply of ecosystem services and influence the quality of living of humanity [5]. The land use/land cover has the ability to affect the biological processes, and modify the supply of ecosystem services [6]. Land use/land cover change has effect on agricultural production [7], greenhouse gas emissions [8], local climate [9] and hydrological fluxes [10].

Over the last several decades, by the fast urban expansion process, the natural landscape was displaced to anthropogenic constructions [11; 4]. Land change is usually conceptualized as key factors that result in land use changes that eventually result in socioeconomic and biophysical impacts [12]. A combination of drivers such as demographic, socio-economic, political, biophysical and technological, have been identified underlying the urbanization of rural municipalities [13]. These change processes are also defined as social responses to increasingly globalized economic circumstances that are mediated by institutions at distinct scales [14]. Understanding the extent, features and pattern of land use/land cover change is a crucial supporting tool for process of making decisions [15; 16].
Identifying land use change over a period of time has being increasingly vital consideration for management of environment [17].

Urban landscape assessment is one of the most important fields of study in urban ecology and landscape architecture, planning and geographic research [18]. Today, urban population is more than 50 percent of the world's population. In recent years, urbanization has dramatically grown in such a way that in 2007 , urban population outweighed rural population for the first time, and evaluations argue that in 2030, almost 60 percent of the world's population will be urban [19]. With the rapid growth of the population, migration from rural areas to the city's outskirts has disrupted the ecological balance, which prevents sustainable socio-economic development in any area [20]. The socioeconomic footprint of urban areas is much higher in comparison with rural areas, which is resulted through blooming the sprawl of the urban areas and becoming increasingly of residents over recent decades [21]

The urban expansion and its negative impacts in Iran have been studied in a number of investigations such as: Tehran [22, 23] Mashhad [24], Kerman [25], Yazd [26; 27], Urmia [28], Kashan [27], Qom [29] and Mazandaran city areas [30]. Iranian cities have been experienced the urbanization phenomenon, particularly since the 1970s. Currently, scientific investigations have been indicated negative effects of urban expansion in Iranian cities containing the devastation natural resources and landscapes across the city [31], degradation and destruction of farmland around the city, decrease in productivity, and risk to food and economic security [29], devastation of groundwater resources [24] and the water shortages, soil and water pollution, rising the charge of urban services, growth in the time and length of intra-city trips [32] and as a consequence, growth in fuel and energy consumption as well as local climate change [33], Social 
segregation [23] and the social capital reduction and rising the rate of crime in the city.

Göksel et al [34] determined the shoreline changes along the Black Sea Coast of Istanbul by applying remote sensing technology. They claimed that the most important changes along the Shoreline was reported at the European side of the city, at a location near to the building area of Istanbul Airport. In another study at the Northern Istanbul of Turkey, Göksel et al, [35] evaluated the landscape transformation and the impact of the third Bosphorus Bridge construction works on the natural ecosystem for a period of seven years. Their result showed that with a fast land cover change at the study area with about $4 \%$ and $\% 1$ decline in forest and green area, $2 \%$ rise in both agricultural and urban/build up areas. Also, the devastated area raised with about $1 \%$ of the study area over 7 years period.

The use and variety of remote sensing data have been developed in the field of evaluation over the past two decades [36, 37]. In this regard, satellite remote sensing can have a major role since in the conventional study, mapping methods are expensive, and they are taking too much time. In addition, availability of such dates are rare for the majority of urban area, particularly in developing countries. Using Landsat TM/OLI images for Land cover/land use classification has evolved over the last few decades. It provides free access with appropriate spatial resolution $(30 \mathrm{~m})$, repetitive coverage and also multispectral monitoring which can enrich the continuous monitoring of land use/land cover dynamics for extended period of time. It also can make it possible to predict future land use [38]. The primary goal of remote sensing applications and the GIS is to provide a map of land cover and land use, and to determine whether the trend of changes is decreasing or increasing over a period of time, or whether the region is resistant to change [39]. On the other hand, the use of satellite data is a good way to prepare land cover maps and monitor them on a large scale [40]. Yuan et al. (2005) [40] used Landsa satellite data in their study to classify land cover and detection of changes in the urban area of Minnesota County, U.S. Moreover, they used a hybrid classification method for classification of the images and used various methods to provide land use and land cover maps.

Masoumi (2012) [27], in a study compered the urbanization pattern in Iranian cities with other western samples. His study indicated basic differences between the urban and suburban sprawl of the North American, West European and Australian cities with Iranian cities. These differences are usually concluded in 5 aspects such as: suburban expansion, single-use developments, disconnection of street network, low accessibility and commercial strip development The Iranian urban expansion dynamics are particularly different in these five aspects. Nevertheless, regardless to these differences, rapid urban sprawl of the Iran's cities has many similarities with developing urban areas of the world including highly automobileoriented urban planning, decline in density of population in the new plans, development of leapfrog and dispersed and lacking the public spaces.

Determining detailed information of land-use change over an extended period of time and urbanization processes are strategic perspectives for understanding driving factors and land-use patterns in Iran, moreover for sustainable land-use planning. Shiraz is a city requiring integrated management due to the rapid urbanization and quick growth of industrial and agricultural uses as well as its historical-cultural and natural values. The current study is aimed at primary realization of the structure and functionality of Shiraz landscape. However, a more comprehensive framework based on ecological, geographic, political and socio-economic considerations is required for better perception of the mechanisms of the landscape patterns.

\section{Material and methods}

\subsection{Study Area}

Shiraz, the capital of Fars province, is one of the most populous cities in Iran. Shiraz is the most developed city in the south of Iran. With an altitude of $1550 \mathrm{~m}$, Shiraz has moderate climate and is located in the mountainous area of Zagros. Its latitude and longitude specifications are $\left(29^{\circ} 53^{\prime} \mathrm{N}, 52^{\circ} 58^{\prime} \mathrm{E}\right)$. With an area of $348 \mathrm{Km} 2$ and a population of 1547129, Shiraz is the third big city in Iran in terms of area and the sixth one in terms of population (fig.1). This city is located on a wide plain with a length of $120 \mathrm{~km}$ and width of $15 \mathrm{~km}$ with a slight slope (5\%) west to east. Shiraz is restricted with Bamo, Kaftarak and Babakouhi mounts in the north, Sabzpooshan Mount in the south, Drak mount in the west and Moharloo lake in the east. Reduced agricultural activity and green space, along with the establishment of industries and increased construction activities, specially road and street construction, has changed the city's image in recent years, leading to an imbalance in the ecosystems.

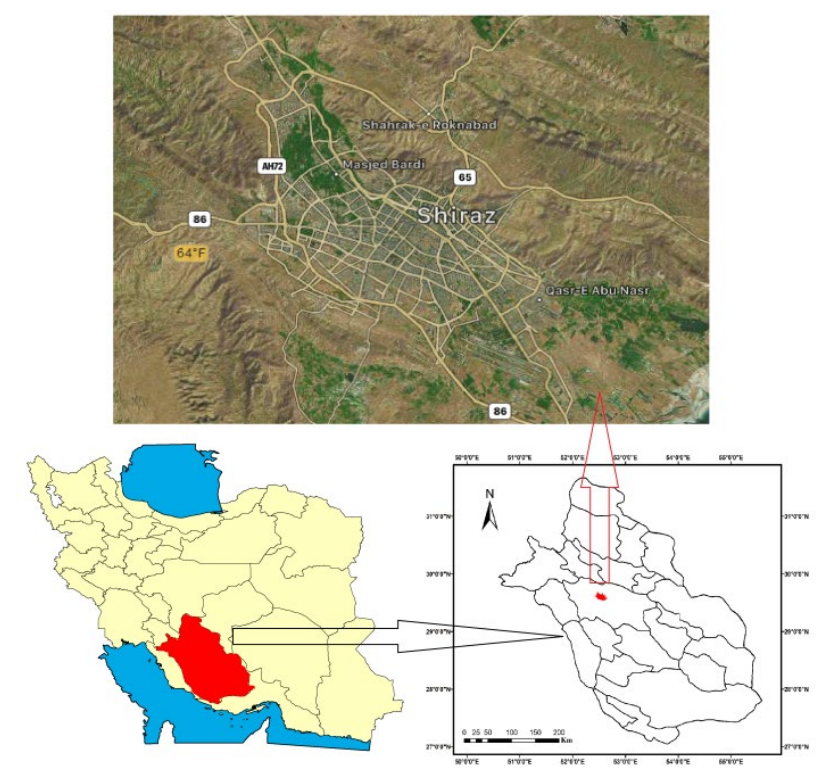

Figure 1. Location of the study area

\subsection{Methodology}

To investigate the change trends in the studied area, Landsat satellite images from MSS, TM and ETM sensors during the years 1982, 1996, 2006 and 2018 were used together with satellite data interpretation and processing software including ERDAS Imaging, IDRISI and Arc GIS 10.1 (Table 1). For this purpose, a preprocessing phase was carried out on the satellite images, including geometric and altitude corrections. To investigate the geometry of the images and to ensure that they are of appropriate geometry, vector layers of roads and streams were extracted from digital maps 1:50000 and were placed on the satellite images. Geometric correction of the images was carried out as follows: geometric correction of an image refers to change the coordinate system of the components of the image and adapt it to similar maps or images that have already been geometrically corrected [41].

First, geometric correction of OLI sensor images for 2018 was carried out using 1:50000 topographic maps of the area. To do so, 38 spots with proper distribution on the image and map were selected and geometric correction was made using the first-order equation and the sampling was performed using the nearest neighbor method. In the next phase, ETM Landsat images for 2018 were recorded on 2018 images. For this purpose, 35 land spots with proper distribution were selected. To make the image land-based, the nearest neighbor method and the first-order polynomial geometric model were used. Geometric correction of TM sensor, 1996, and MSS sensor, 1982, was carried out selecting 32 and 35 land-control spots, respectively, with proper distribution, using nearest neighbor method and the first-order polynomial geometric model. Table1 shows the RMSE of each image. The Root Mean Square Error (RMSE)is a popular parameter which can apply for measure of the difference among values predicted using a model and the values actually observed from the environment that is being modeled. To calculate the RMSE, the following equation is used (Eq 1):

$R M S E=\sqrt{\frac{\sum_{i=1}^{n}\left(X_{o b s, i}-X_{\text {model }, i}\right)^{2}}{n}}$ 
where $\mathrm{X}_{\text {obs }}$ is observed values and $\mathrm{X}_{\text {model }}$ is modelled values at time/place $\mathrm{i}$.

Kok et al. (2001) [42] claim that the choosing of resolution should be taken into account the aim of the modeling application and the scales of the processes of land change. Thus, we carefully and intentionally chose this images to evaluate whether the same procedure was regularly effective in recognizing similar classes in urban areas with various environmental settings.

Image enhancement can be defined as a conversion operation to enhance the quality of images to a better and understandable level in order to extract patterns or interpret images. One of the most important ways of image enhancement is to produce false color images. From the combination of 3 different bands and assigning each of the three primary colors (red, green and blue) to each satellite image band, a false color image is created. The purpose of selecting suitable bands for making color images is to minimize low-value data and to use valuable data.

Table 1: RMSE of each class of image

\begin{tabular}{lll}
\hline Image & $\begin{array}{l}\text { No. of land- } \\
\text { control spots }\end{array}$ & RMSE \\
\hline Landsat OLI sensor(2018) & 38 & 0.43 \\
\hline $\begin{array}{l}\text { Landsat ETM sensor } \\
(2006)\end{array}$ & 35 & 0.54 \\
\hline Landsat TM sensor (1996) & 32 & 0.44 \\
\hline $\begin{array}{l}\text { Landsat MSS sensor } \\
\text { (1982) }\end{array}$ & 35 & 0.41 \\
\hline
\end{tabular}

Land cover maps of the study area were prepared using a supervised classification method. In supervised classification, for each phenomenon, a number of areas or levels were selected as samples or training areas to be used for classifying the information in later stages. In this method, the number of variances and the correlation of the spectral values of different bands were calculated for sample regions, and this property is also used to associate a pixel classification with one of the spectral samples.

To prepare land cover map, a number of training samples were taken as polygons for each use through examining the image in terms of quality and carrying out the field operations, in a way that each polygon contained only pixels of a specific use. It was tried to select training samples with proper distribution. Then, the training samples were introduced into the software as signature file, and land cover maps of the coming years were also prepared via maximal likelihood method. We classified the images into five categories: agriculture, urban area, bare land, tree cover and street (Table 2). The selection of categories that we used in the classification was on the basis of resolution of satellite data and the marking of different feature classes throughout our visit to the study area. Shiraz is the cultural capital of Iran, and since ancient times been known as the city of flowers and nightingales. The city was once famous for its parks and gardens, which urbanization has displaced to other urban needs. Gardens plays a crucial role in the spatial organization of the Shiraz. Therefore, this classification method was selected due to its reflectivity of intense land use changes and the visual differences in land use types.
Table2: categorization of land cover map

\begin{tabular}{cc}
\hline Category & Description \\
\hline Agriculture & Agricultural land and Fallow land \\
\hline Tree cover & $\begin{array}{c}\text { Gardens and orchards, Green space and } \\
\text { Parks }\end{array}$ \\
\hline Bare land & $\begin{array}{c}\text { Bare land, Solon chak, Weak pastures, } \\
\text { Mounts and Lands without any } \\
\text { construction }\end{array}$ \\
\hline Street & $\begin{array}{c}\text { Street and Road } \\
\text { Urban }\end{array}$ \\
\hline
\end{tabular}

The most common and standard method for determining the accuracy of classified maps is to use an error matrix. Another method is using general accuracy which is one of the indicators used to express the accuracy of the results obtained from different classification methods. General accuracy can be a criterion for determining the accuracy of classification by dividing the set of correctly classified pixels of all classes into the total reference pixels. The Kappa coefficient can also be used to compare the classification results. The value of the Kappa coefficient varies between zero and one; the closer to one, the closer is the accuracy of the map derived from the classification to the reality, with the value 1 representing full agreement $(100 \%)$ of the classification map with reality. In terms of the theory of probabilities, general accuracy cannot be a good measure for evaluating the results of the classification, because in this indicator, the role of chance is significant. For this reason, the Kappa Index is often used to determine the accuracy of results from different classification methods [43]. It is defined as Eq (2).

$K=\left(P_{0}-P_{e}\right) /\left(1-P_{e}\right)$

where $P_{0}$ is the empirical probability of agreement on the label assigned to any sample (the observed agreement ratio), and $P_{e}$ is the expected agreement when both annotators assign labels randomly. For this purpose, 70 spots were selected via random sampling, and the accuracy of the classification was examined based on relative cognition of the area under study and Google earth software as well as GPS application in field studies; accuracy matrix of each map was prepared accordingly (Table 3). The overall methodology flowchart of the process is indicated in Fig. 2.

Table3: Kappa coefficient and general accuracy of land use maps

\begin{tabular}{lcc}
\hline Land use map & Kappa coefficient & $\begin{array}{c}\text { General } \\
\text { accuracy }\end{array}$ \\
\hline OLI 2018 & 0.78 & 90.5 \\
\hline ETM 2006 & 0.79 & 91.5 \\
\hline TM 1996 & 0.78 & 91 \\
\hline MSS 1982 & 0.80 & 92.2 \\
\hline
\end{tabular}

The applicability of any generated map depends on its accuracy. Hence, after categorization, the classes must be compared with the reality and also the accuracy of the classes is estimated. The purpose of the verification is to assess the degree to which the maps are matched with real land use. By comparing each map pixel with the corresponding pixels in the real-earth map, one can determine how many pixels are correctly categorized in different classes and how many have been mistakenly assigned to different classes. 


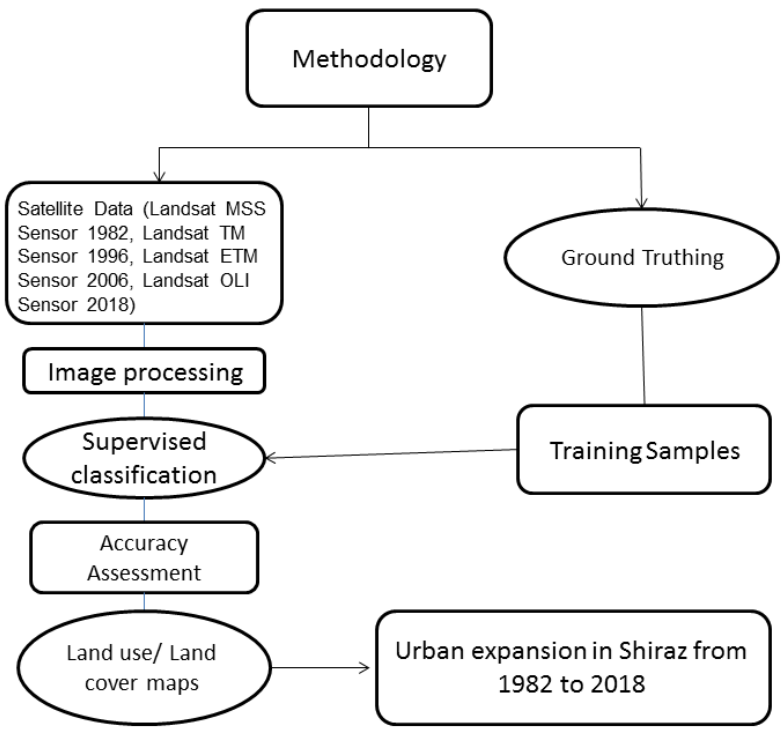

Figure 2. Flow chart of urban expansion analysis process.

\section{Results}

Land cover maps of 1982, 1996, 2006 and 2018 are represented in figures 3, 4, 5 and 6 . Results of the classification and comparison of the maps showed that $2 \%$ of the tree cover was degraded between 1982 and 2018 as shown in Figures 3 to 6. Mostly tree cover has been transformed into residential and man-made lands. Economic growth and urban development, as well as migration from villages to cities, are the major causes of these changes. This can also justify the reduction in agricultural lands. Here, the increased price of residential land is a major factor. In fact in 1982, almost $11 \%$ of the area is agricultural land which is reduced to $3.70 \%$ in $1996,3.30 \%$ in 2006 and $2.65 \%$ in 2018. The most important change in land use is the increase in urban area and streets.

According to figures 3-5 and table4, 30.50\% of land with various uses has transformed into urban area. Based on figures 3 and 4, this development can be observed throughout the area, affecting land uses such as agriculture and even bare land.

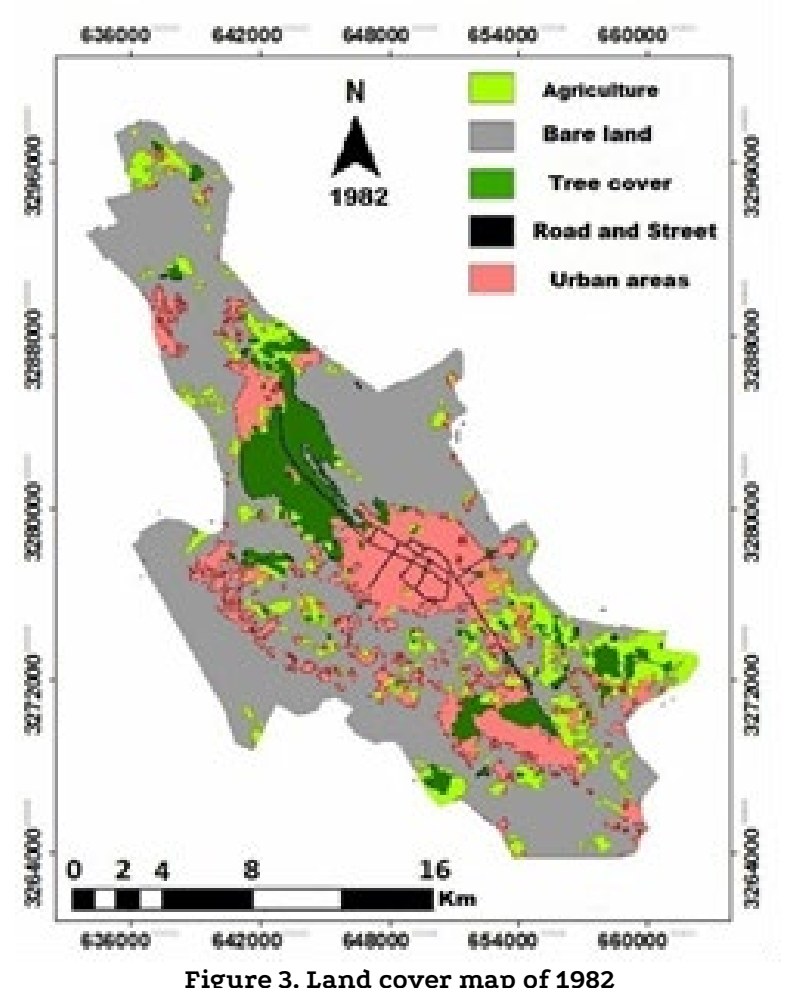

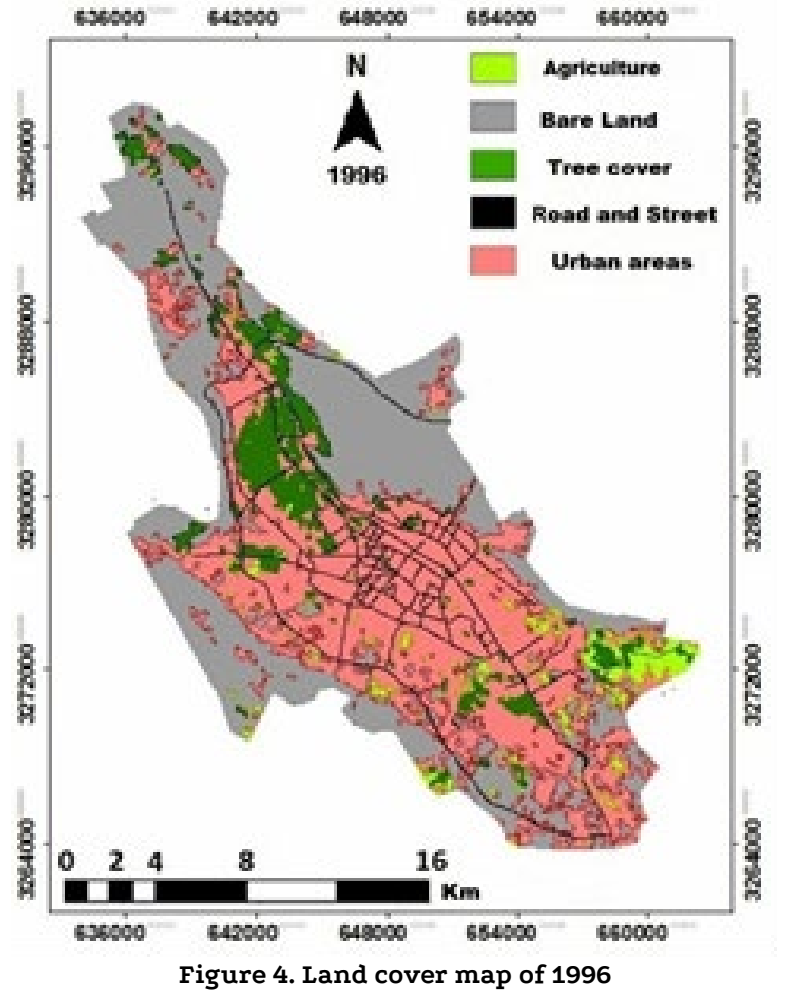

The $8.35 \%$ reduction in agriculture land and $2 \%$ reduction in tree cover have been due to the development of urban area caused by economic and demand growth. Climate change and decreased water reserves over the recent years can also be important factors, but conversion to residential area is still the main factor. Based on figures 3 and 4, the main cause of this degradation is development of urban area.

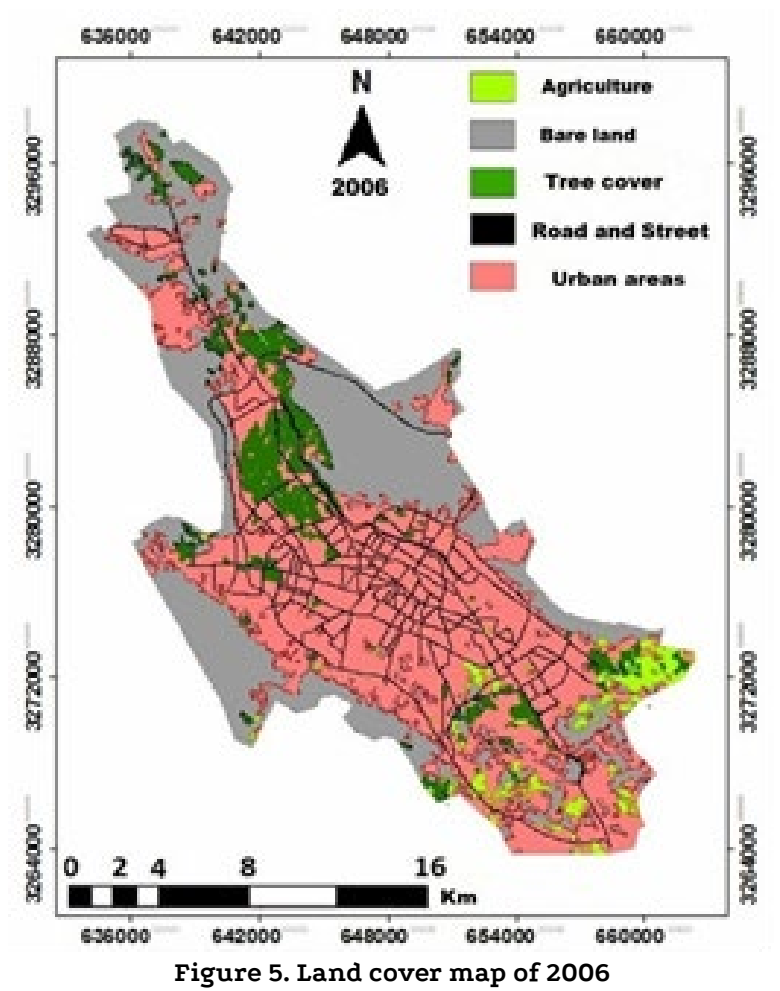




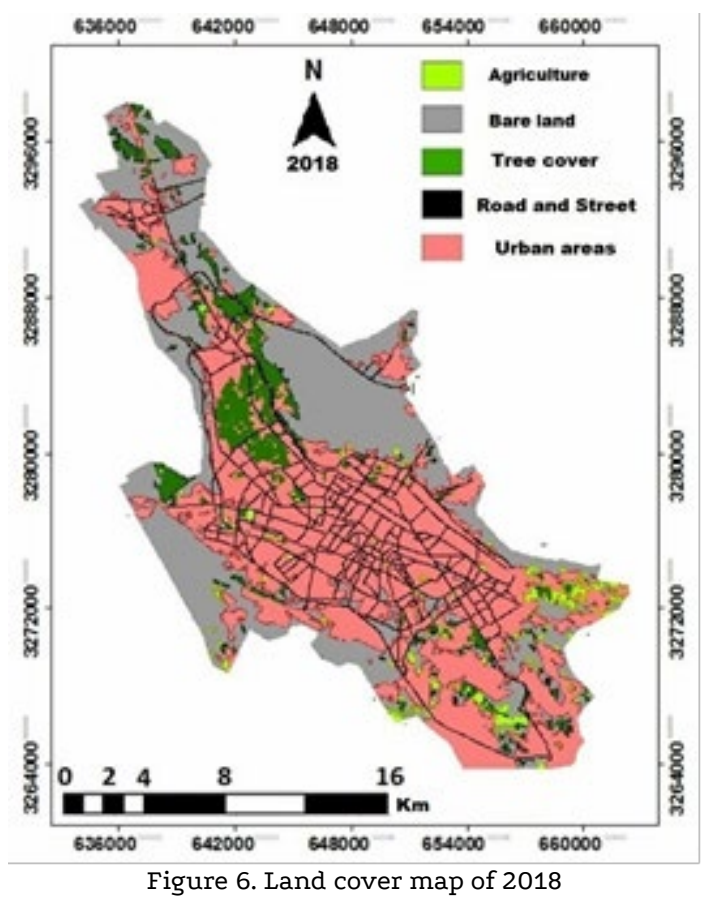

Figure 7 illustrates the changes and percentage of various uses in the study area. The reduction in agriculture, bare land and tree cover are absolutely apparent. The most significant changes were within the first period (1982-1996). According to figure 7, conversion of agriculture and bare land to urban area in this period is much more considerable than other periods. As it can be observed in this figure, the percentage of urban area and street (or road) has experienced a significant rise throughout the studied periods.

Table 4: Changes in the area under various uses in the studied region (1982-2018)

\begin{tabular}{|c|c|c|c|c|c|c|c|c|}
\hline \multirow{2}{*}{$\begin{array}{l}\text { Land } \\
\text { use } \\
\text { and } \\
\text { cover }\end{array}$} & \multicolumn{2}{|l|}{1982} & \multicolumn{2}{|l|}{1966} & \multicolumn{2}{|l|}{2006} & \multicolumn{2}{|l|}{2018} \\
\hline & ha & $\%$ & ha & $\%$ & ha & $\%$ & ha & $\%$ \\
\hline $\begin{array}{l}\text { Agricu } \\
\text { lture }\end{array}$ & $\begin{array}{l}4182 . \\
03\end{array}$ & 11 & $\begin{array}{l}1407 . \\
90\end{array}$ & $\begin{array}{l}3.7 \\
0\end{array}$ & $\begin{array}{l}1260 . \\
10\end{array}$ & $\begin{array}{l}3.3 \\
0\end{array}$ & $\begin{array}{l}1010 \\
.25\end{array}$ & $\begin{array}{l}2.6 \\
5\end{array}$ \\
\hline $\begin{array}{l}\text { Bare } \\
\text { land }\end{array}$ & $\begin{array}{l}2372 \\
8.70\end{array}$ & $\begin{array}{l}62 . \\
25\end{array}$ & $\begin{array}{l}1722 \\
6.70\end{array}$ & $\begin{array}{l}45 . \\
30\end{array}$ & $\begin{array}{l}1510 \\
8.40\end{array}$ & $\begin{array}{l}39 . \\
50\end{array}$ & $\begin{array}{l}1510 \\
8.30\end{array}$ & $\begin{array}{l}39 . \\
50\end{array}$ \\
\hline $\begin{array}{l}\text { Tree } \\
\text { cover }\end{array}$ & $\begin{array}{l}3514 . \\
40\end{array}$ & $\begin{array}{l}9.2 \\
0\end{array}$ & $\begin{array}{l}3446 . \\
90\end{array}$ & $\begin{array}{l}9.1 \\
0\end{array}$ & $\begin{array}{l}3174 . \\
40\end{array}$ & $\begin{array}{l}8.3 \\
0\end{array}$ & $\begin{array}{l}2748 . \\
60\end{array}$ & $\begin{array}{l}7.2 \\
0\end{array}$ \\
\hline $\begin{array}{l}\text { Street } \\
\text { and } \\
\text { road }\end{array}$ & $\begin{array}{l}99.6 \\
0\end{array}$ & $\begin{array}{l}0.2 \\
5\end{array}$ & $\begin{array}{l}609 . \\
30\end{array}$ & $\begin{array}{l}1.6 \\
0\end{array}$ & $\begin{array}{l}933.0 \\
3\end{array}$ & $\begin{array}{l}2.5 \\
0\end{array}$ & $\begin{array}{l}1097 . \\
90\end{array}$ & $\begin{array}{l}2.8 \\
5\end{array}$ \\
\hline $\begin{array}{l}\text { Urban } \\
\text { area }\end{array}$ & $\begin{array}{l}6596 . \\
30\end{array}$ & $\begin{array}{l}17 . \\
30\end{array}$ & $\begin{array}{l}1533 \\
1.95\end{array}$ & $\begin{array}{l}40 . \\
30\end{array}$ & $\begin{array}{l}1770 \\
9.40\end{array}$ & $\begin{array}{l}46 . \\
40\end{array}$ & $\begin{array}{l}1827 \\
9.50\end{array}$ & $\begin{array}{l}47 . \\
8\end{array}$ \\
\hline
\end{tabular}

Comparison of the changes in land use/ land cover over the three studied periods revealed significant difference in the severity of the changes. To compare the severity of changes during these three periods, average changes in each year were firstly estimated and compared, as shown in figure8. In this figure, the sign (-) depicts reduction of the area while the sign (+) shows increase in the area. Based on the data, the rate of change for urban area is the most sever during the first period, indicating tremendous changes between 1982 and 1996. During these years, urban area has increased by $624 \mathrm{Ha}$ per year on the average, while this rate is $238 \mathrm{Ha}$ for the next decade (1996-2006). Agricultural area has decreased by $198 \mathrm{Ha}$ per year during the first period (1982-1996). This rate is 14 and $19 \mathrm{Ha}$ for the second and third periods, respectively. This shows increasing and decreasing rate of change in land use and land cover over the three studied periods. Dramatic changes in the first period can be due to considerable migration to cities and increased urbanization.

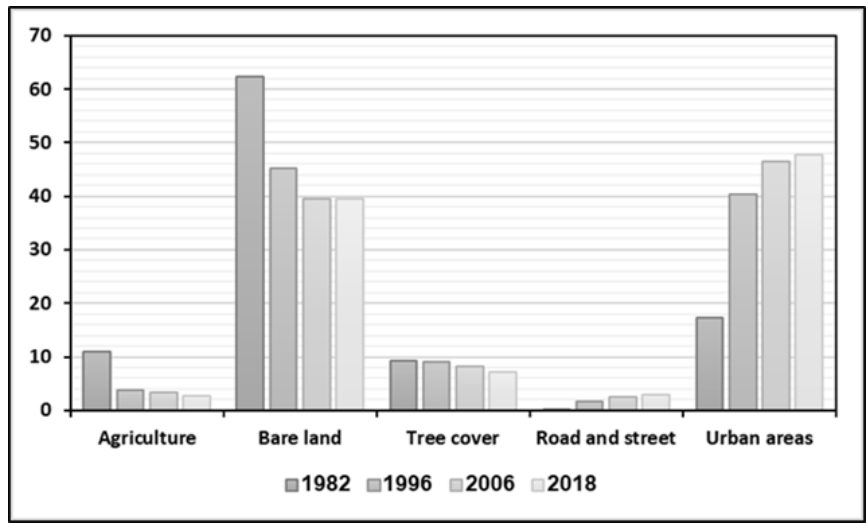

Figure 7. Percentage of changes in land use and cover

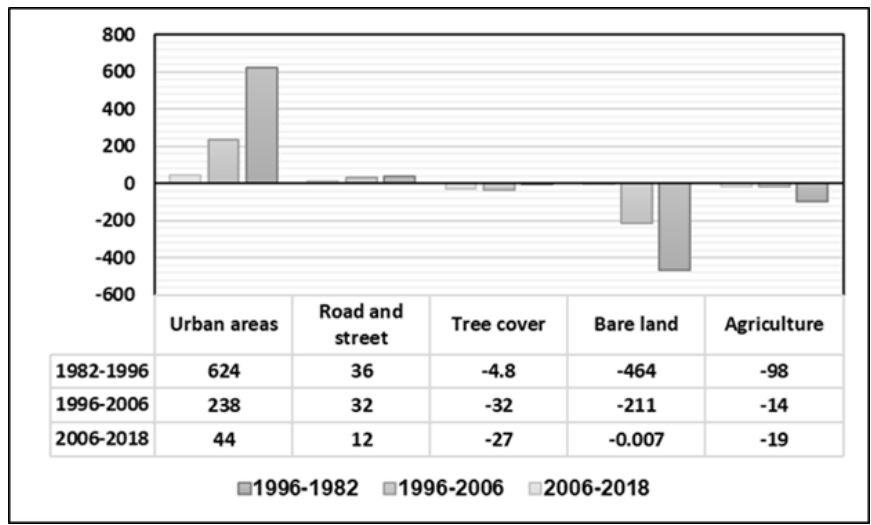

Figure 8. Annual change in land use and cover over the three studied periods

\section{Discussion}

Changes in different classes of land use/cover during 1986 to 2018 has been present in table 4 . There has been a conversion from agricultural and bare lands to urbanizing area caused by rapid urban sprawl. The growth of urban area during the study periods was associated with rapid growth in population and in-migration from neighboring cities and villages. Unfortunately, this rapid growth in population led to the destruction of some vegetation cover. This means that construction advanced at the expense of vegetation cover reduction. Shiraz residents have been getting out of the border of Shiraz during last decades and they are using not only bare lands, but rural areas and farmlands. Researches including Mosammam et al. (2017) [44] and te Lintelo et al. (2018) [45] also identified that the rapid urban transition is a major challenge in the twenty-first century.

The urban area depicts increasing trend from 1982 to 2018 covering an area of 6596.30 ha $(17.30 \%)$ in the $1982,15331.95$ ha $(40.30 \%)$ in the $1996,17709.40$ ha $(46.40 \%)$ in the 2006 and 12years later this land use class expanded to 18279.50 ha $(47.8 \%)$ in the 2018. Abebe et al. (2019) [16] and $\mathrm{Wu} \&$ Zhang (2012) [46] in their studies also investigated comparable findings with growth in urban transition. Their study indicated that built-up area have been increasing during last two decades. Also, there have been an increasing trends in road and street. Bare land that covered over 23728.70 ha $(62.25 \%)$ in 1982 , dwindled to 15108.30 ha (39.50\%) in 2018 (districts 4, 9, 5, 2, 7 and 10). Lejano and Bianco (2018) [47] have also shown that the decreasing in bare land area is as a result of requiring for house construction, which informal house construction problems increases.

It is observed that the tree cover has slightly decreased from 3514.40 $(9.20 \%)$ in the 1982 to 3446.90 (9.10\%) in the 1996, and the decreasing trend of tree cover is continued during the study periods to 2748.60 (7.20\%) by 2018 (districts 6 and 2). Urban sprawl growths fast, entered 
into the field of gardens and changed their land use. Unfortunately, in return for rapid urban expansion what is lost is the lung of Shiraz which it left an irreparable negative environmental impact. This was happened for agricultural land too. Also, in recent years as a result of increasing in prices of land to constructing buildings, the gardens have dried up and destroyed. The agricultural land shows decreasing trend from 1982 to 2018 covering an area of 4182.03 (11\%) in 1982 and $1010.25(2.65 \%)$ in 2017 (districts 7, 10, 6, 4 and 9). Consequently there have been a serious decline in agricultural and horticultural production which it can pose a threat for safety and security of residents. Our findings show that peri-urban development has happened primarily on agricultural land (mainly on district 7) where available, in line with findings by [46] and the European Environment Agency [49]. Urbanization in Shiraz have eliminated most of the farmlands over last decades. If the rates of this elimination be continued to 2040, Shiraz will loss most of its agricultural lands. Croplands are vital because of the fact that they supply the major food products of the residents. Ownership of farmland is critically important for the sustainable life of rural inhabitants and losing it may result in poverty [50] and interruption of life in rural areas, consequently increasing migration.

The highest positive change have seen in urban area, especially during 1982-1996, whereas the highest negative change have seen in bare land during the year 1982-1996. It is clear that several major changes have occurred during first period of study. The research has shown that the urban area is increasing in the outskirts of the city, particularly in south (districts 2, 5 and 9) and the southeastern (district 7) part of the city (Fig. 2. 3. 4 \& 5). Such increasing in the outskirts of the city is mostly caused by rapid population of the city [16]. Many studies declared on dispersion of population from urban cores to surrounding regions, either as result of economic pressures or for lifestyle reasons. However, researches including [51] and [52] pointed out that the major proportion of new immigrants to outskirts of the city are from rural backgrounds originally. Cheaper rents, declining travel times to urban cores, higher space availability, and local requirement for products and services are all items that attract businesses in the outskirts of the city [53; 54]. The current study indicated that the urban areas have expanded, which these results are consistent with [55] and [56]. As maintained by [55], rapid population explosion and economic progress has resulted in growth of cities. Having knowledge about land use/cover change is essential to strengthen the effectiveness of the urban planning of cities and it is very much important supporting tool for process of making decisions.

Researches demonstrate that fast and unplanned urban sprawl has threatened the environment and citizens' security and health in Iran. There is a hope that by means of policy changes and planning in the future, more sustainable and habitable cities create. In this context, it is estimated to improve the citizen's lives, the preserve of green spaces, and their area enhance throughout the city and then applying programs to learn energy conservation in society. Finally, due to drought and water shortage over the past years, some solutions are suggested to supply water particularly rainwater harvesting, and store water in agricultural field with the intention of prevent garden and crop destruction. It could help to avoid migration from rural area to urban area and control the population growth in the cities.

\section{Conclusion}

Changes in land use over the study area were investigated, and the change patterns and effective factors were examined using satellite imagery and geographic information system. Five types of land cover/use were identified, and the urban area was determined to be the most important land use with the greatest growth over the studied periods. Tree cover has considerably been degraded and, in most cases, has transformed into urban area. This trend is still increasing in the area. It is predicted that tree cover may completely disappear on the area in absence of appropriate management. However, it must be mentioned that during the recent years, efforts have been made to plant trees, but this trend is very slow. Hence, city officials are recommended to consider planting trees and expanding green space in the area. Since Shiraz is of great significance in terms of urbanization and centrality, fundamental operations must be considered for effective management of the area. Economic development in the neighboring small towns, to prevent migration to big cities, is regarded as an effective method of land management in such areas, which seems to be effective in the study area.

\section{Declaration of Conflict of Interests}

The authors declare that there is no conflict of interest.

\section{References}

[1.] Ramankutty, N., Coomes, O.T. Land-use regime shifts: An analytical framework and agenda for future land-use research. Ecology and Society, (2016)vol. 21, no. 2 https://doi.org/10.5751/ES-08370-210201

[2.] Ranpise, R.S., Kadam, A.K., Gaikwad, S.W., Meshram, D.C. Appraising Spatio-Temporal Shifting of Urban Growth Center of Pimpri-Chinchwad Industrialized City, India Using Shannon Entropy Method. Current Urban Studies, (2016) vol. 4, p. 343355. https://doi.org/10.4236/cus.2016.43023

[3.] Dissanayake, D., Morimoto, T., Murayama, Y., Ranagalage, M. Impact of landscape structure on the variation of land surface temperature in sub-saharan region: A case study of Addis Ababa using Landsat data (1986-2016). Sustainability (2019), 11, 2257. https://doi.org/10.3390/su11082257

[4.] Ranagalage, M., Dissanayake, D., Murayama, Y., Zhang, X., Estoque, R.C., Perera, E., Morimoto, T. Quantifying surface urban heat island formation in the world heritage tropical mountain city of Sri Lanka. ISPRS Int. J. Geo Inf. (2018), 7, 341. https://doi.org/10.3390/ijgi7090341

[5.] Rimal, B., Sharma, R., Kunwar, R., Keshtkar, H., Stork, N.E., Rijal, S., Rahman, S.A, Baral, H. Effects of land use and land cover change on ecosystem services in the Koshi River Basin, Eastern Nepal. Ecosyst Serv (2019) 38:100963. https://doi.org/10.1016/j.ecoser.2019.100963

[6.] Gibson, L., Munch, Z., Palmer, A., Mantel, S. Future land cover change scenarios in South African grassland-implications of altered biophysical drivers on land management. Heliyon. (2018) Jul; 4(7): e00693. https://doi: 10.1016/j.heliyon.2018.e00693

[7.] Deng, X., Li, Z., Huang, J., Shi, Q., Li, Y. A revisit to the impacts of land use changes on the human wellbeing via altering the ecosystem provisioning services. Adv Meteorol. (2013). https://doi.org/10.1155/2013/90736 7

[8.] Furukawa, T., Kayo, C., Kadoya, T., Kastner, T., Hondo, H., Matsuda, H., Kaneko, N. Forest harvest index: Accounting for global gross forest cover loss of wood production and an application of trade analysis. Glob Ecol Conserv, (2015), 4:150159. https://doi.org/10.1016/j.gecco.2015.06.011

[9.] Geng, X., Wang, X., Yan, H., Zhang, Q., Jin, G. Land use/land cover change induced impacts on water supply service in the upper reach of Heihe River Basin. Sustainability, (2015), 7:366-383. https://doi.org/10.3390/su7010366

[10.] Guzha, A.C., Rufino, M.C., Okoth, S., Jacobs, S., Nobrega, R.L.B. Impacts of land use and land cover change on the surface runoff, discharge and low flows: evidence from East Africa. EJRH,

15:49-67.

[11.] Ranagalage, M., Estoque, R.C., Murayama, Y. An urban heat island study of the Colombo metropolitan area, Sri Lanka, based on Landsat data (1997-2017). ISPRS Int. J. Geo-Inf. (2017), 6, 189. https://doi.org/10.3390/ijgi6070189

[12.] Turner, B.L., Lambin, E.F., Reenberg, A. The emergence of land change science for global environmental change and sustainability. Proceedings of the National Academy of Sciences of the United States of America, (2007), 104, 20666-20671. https://doi.org/10.1073/pnas.0704119104.

[13.] Plieninger, T., Draux, H., Fagerholm, N., Bieling, C., Bürgi, M., Kizos, T., Verburg, P.H. The driving forces of landscape change in Europe: A systematic review of the evidence. Land Use Policy, (2016), 57, 204-214. https://doi.org/10.1016/j.landusepol.2016.04.040.

[14.] Lambin, E.F., Turner, B.L., Geist, H.J., Agbola, S.B., Angelsen, A., Bruce, J.W., $\mathrm{Xu}$, J. The causes of land-use and land-cover change: Moving beyond the myths. Global Environmental Change, (2001), 11, 261-269. https://doi.org/10.1016/S09593780(01) 00007-3.

[15.] Armenteras, D., Murcia, U., Gonzalez, TM., Baron, O.J., Arias, J.E. Scenarios of land use and land cover change for NW Amazonia: impact of forest intactness. Glob Ecol Conserv, (2019), 17:e00567. https://doi.org/10.1016/j.gecco.2019.e00567

[16.] Abebe, M.S., Derebew, K.T., Gemeda, D.O. Exploiting temporalspatial patterns of informal settlements using GIS and remote sensing technique: a case study of Jimma City, Southwestern 
Ethiopia. Environ Syst Res. (2019), https://doi.org/10.1186/s4006 8-019-0133-5

[17.] Mensah, A.A., Sarfo, D.A., Partey, S.T. Assessment of vegetation dynamics using remote sensing and GIS: a case of Bosomtwe Range Forest Reserve, Ghana. Egypt J Remote Sense Space Sci (TSI), (2019), https://doi.org/10.1016/j.ejrs.2018.04.004

[18.] Zhu, M., Xu, J., Jiang, N., Li, J., Fan, Y. Impacts of road corridors on urban landscape pattern: a gradient analysis with changing grain size in Shanghai, china. Landscape Ecol,vol. (2006), 21,pp.723-734. https://doi.org/10.1007/s10980-005-5323-z

[19.] UNEP,(2007). Global Environmental Outlook GEO4. Environmental for development. United Nations Environment program. p. 54.

[20.] Srivastava, S.K., Gupta, R.D.B. Monitoring of changes in land use/ land cover using multi-sensor satellite Data, 6th International Conference on GIS /GPS/RS: Map India (2003), Jan.28-31, New Delhi, 234-251.

[21.] United Nations. UN Department of Economic and Social Affairs, The World's Cities in 2018; United Nations: New York, NY, USA, (2018).

[22.] Dadashpoor, H., Nateghi, M. Simulating spatial pattern of urban growth using GIS-based SLEUTH model: a case study of eastern corridor of Tehran metropolitan region, Iran. Environ. Dev. Sustain. (2017), 19 (2), 527-547. https://doi.org/10.1007/s10668015-9744-9.

[23.] Zali, N., Hashemzadeh Ghal'ejough, F., Esmailzadeh, Y. Analyzing urban sprawl of Tehran metropolis in Iran (during 1956-2011). Anuário do Instituto de Geociências, (2016). 39(3), 55-62. http://dx.doi.org/10.11137/2016_3_55_62.

[24.] Hosseini, A., Shabanifard, M., Rashidi, M., Saiydzade, M.R. Distribution and Determining of Urban Sprawl in Kerman with Emphasis on Kariz Water System, Physics International, (2010), 1(1), pp.9-15. DOI: https://doi.org/10.3844/pisp.2010.9.15

[25.] Hosseini, S.A., Zanganeh Shahraki, S., Farhudi, R., Hosseini, S.M., Salari, M., Pourahmad, A. Effect of urban sprawl on a traditional water system (qanat) in the City of Mashhad, NE Iran. Urban Water Journal, (2014), 7(5), 309-320. http://dx.doi.org/10.1080/1573062X.2010.484497.

[26.] Shahraki, S.Z., Sauri, D., Serra, P., Modugno, S., Seifolddini, F. Pourahmad, A. Urban Sprawl Pattern and Land-Use Change Detection in Yazd, Iran. Habitat International, (2011), 35(4), pp.521-528. https://doi.org/10.1016/j.habitatint.2011.02.004

[27.] Masoumi, H.E. Urban sprawl in Iranian cities and its differences with the western sprawl. SPATIUM International Review, (2012), 27, 12-18. http://dx.doi.org/10.2298/SPAT1227012E.

[28.] Mobaraki, O., Mohammadi, J., Zarrabi, A. Strategy for Sustainable Urban Development: A Case Study of Urmia City, Iran. Greener Journal of Social Sciences,Vol. (2012), 2 (1), pp. 041049. DOI: $10.15580 / G J S S .2012 .1 . G J S S 1203$

[29.] Mohammadian Mosammam, H., Tavakoli Nia, J., Khani, H. Teymouri, A., Kazemi, M. Monitoring land use change and measuring urban sprawl based on its spatial forms, the case of Qom city. Egyptian Journal of Remote Sensing and Space Science. (2016). http://dx.doi.org/10.1016/j.ejrs.2016.08.002.

[30.] Dadashpoor, H., Salarian, F. Urban sprawl on natural lands: analyzing and predicting the trend of land use changes and sprawl in Mazandaran city region, Iran. Environ. Dev. Sustain. (2018), 1-22 https://doi.org/10.1007/s10668-018-0211-2.

[31.] Soltani, A., Hosseinpour, M., Hajizadeh, A. Urban sprawl in Iranian medium-sized cities; investigating the role of Masterplans. International Journal of Sustainable Development, (2017). 10(1), 122-131. DOI: 10.5539/jsd.v10n1p122

[32.] Mohammady, S, Delavar, M.R. Urban sprawl modelling. The case of Sanandaj City, Iran. Journal of Settlements and Spatial Planning, (2014). 5(2), 83-90

[33.] Zanganeh Shahraki, S., Sauri, D., Serra, P., Modugno, S. Seifolddini, F., Pourahmad, A. Urban sprawl pattern and landuse change detection in Yazd, Iran. Habitat International, (2011)

$521-528$ http://dx.doi.org/10.1016/j.habitatint.2011.02.004.

[34.] Goksel C, Senel G, Dogru Ao. Determination of shoreline change along the Black Sea coast of Istanbul using remote sensing and GIS technology. Desalination and Water Treatment. 177 (2020) 242-247. doi:10.5004/dwt.2020.24975

[35.] Goksel C, David RM, Doğru A Ö. Environmental Monitoring of Spatio-Temporal Changes in Northern Istanbul using Remote
Sensing and GIS. International Journal of Environment and $\begin{array}{lll}\text { Geoinformatics } & 5(1): & 94-103\end{array}$ https://doi.org/10.30897/ijegeo.410943

[36.] Rogan J, Franklin J, Roberts DA. A comparison of methods for monitoring multi-temporal vegetation change using Thematic Mapper imagery, Remote Sens. Environ. (2002), Vol.80, pp.143-156. https://doi.org/10.1016/S0034-4257(01)00296-6

[37.] Healey SP, Cohen WB, Zhiqiang Y, Krankina ON. Comparison of Tasseled Cap-based Landsat data structures for use in forest disturbance detection. Remote Sensing of Environment. (2005), Vol. 97, pp. 301-310. https://doi.org/10.1016/j.rse.2005.05.009

[38.] Islam, K., Jashimuddin, M., Nath, B., Nath, T.K. Land use classification and change detection by using multi-temporal remotely sensed imagery: The case of Chunati wildlife sanctuary, Bangladesh. The Egyptian Journal of Remote Sensing and Space Science, (2018), 21 (1), 37-47.

[39.] Hansen, M.C., Shimabukuro, Y.E., Potapov, P., Pittman, K. Comparing amual MODIS and PRODES forest cover change for an advancing monitoring of Brazilian forest cover. Remote Sensing of Environment. (2008), v112: 3784 - 3793 PP. https://doi.org/10.1016/j.rse.2008.05.012

[40.] Yuan, F., Sawaya, K.E., Loeffelholz, B.C., Bauer, M.E. Land cover classification and change analysis of the Twin Cities (Minnesota) Metropolitan Area by multitemporal Landsat remote sensing. Remote sensing of Environment, (2005), 98(2), pp.317-328. https://doi.org/10.1016/j.rse.2005.08.006

[41.] Lillesand, T., Kiefer, R.W., Chipman, J. Remote sensing and image interpretation john Wiley \& sons, USA, (1994)

[42.] Kok, K., Farrow, A., Veldkamp, T.A., Verburg, PH. A method and application of multi-scale validation in spatial land use models. Agric Ecosyst Environ, (2001), 85(1-3):223-238. https://doi.org/10.1016/S0167-8809(01)00186-4

[43.] Park, R.E., Burgess, E.W., McKenzie, R. The City in, Univhersity of Chicago Press, Chicago, Illinois, USA. (1925).

[44.] Mosammam, H.M., Nia, J.T., Khani, H., Teymouri, A., Kazemi, M. Monitoring land use change and measuring urban sprawl based on its spatial forms. The case of Qom city. Egypt J Rem sense Space Sci, (2017), 20:103-116. https://doi.org/10.1016/j.ejrs.2016.08.002

[45.] te Lintelo, D.J.H., Gupte, J., McGregor, J.A., Lakshman, R., Jahan, F. Wellbeing and urban governance: who fails, survives or thieves in informal settlements in Bangladeshi Cities? Cities. (2018), 72:391-402. https://doi.org/10.1016/j.cities.2017.10.002

[46.] Wu, K., Zhang, H. Land use dynamics, built-up land expansion patterns, and driving forces analysis of the fast-growing Hangzhou metropolitan area, eastern China (1978-2008), Applied Geography, (2012), p. 137-145. https://doi.org/10.1016/j.apgeog.2011.11.006

[47.] Lejano, R.P., Bianco, C.D. The logic of informality: pattern and process in a Sao Paulo favela. Geoforum, (2018), 91:195-205. https://doi.org/10.1016/j.geoforum.2018.03.005

[48.] Shaw, B.J., van Vliet, J., Verburg, P.H. The peri-urbanization of Europe: A systematic review of a multifaceted process. Landscape and Urban Planning 196 (2020) 103733. https://doi.org/10.1016/j.landurbplan.2019.103733

[49.] Agency, E. E. Ecosystems services - Accounting for what matters. (2008)

[50.] Tacoli, C., Mabala, R. Exploring mobility and migration in the context of rural-urban linkages: Why gender and generation matter. Environment and Urbanization, (2010), 22(2), 389-395. http://dx.doi.org/10.1177/0956247810379935

[51.] Van Der Vaart, J.H.P. Towards a new rural landscape: Consequences of non-agricultural re-use of redundant farm buildings in Friesland. Landscape and Urban Planning, (2005), 70, 143-152. https://doi.org/10.1016/j.landurbplan.2003.10.010.

[52.] Gkartzios, M., Scott, M. Residential mobilities and house building in rural Ireland: Evidence from three case studies.

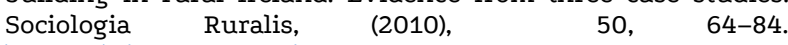
https://doi.org/10.1111/j.14679523.2009.00502.x.

[53.] Busck, A.G., Hidding, M.C., Kristensen, S.B.P., Persson, C. Praestholm, S. Planning approaches for urban areas: Case studies from Denmark, Sweden and the Netherlands. Geografisk Tidsskrift, (2009), 109, 15-32. https://doi.org/10.1080/00167223.2009.10649593

[54.] Sallay, A., Jombach, S., Filepné Kovács, K. Landscape changes and function lost landscape values. Applied Ecology and Environmental Research, (2012), 10, 157-172. https://doi.org/10.15666/aeer/1002_157172. 
[55.] Nassar, D.M., Elsayed, H.G. From informal settlements to sustainable communities. Alexandria Eng J, (2017), 57(4):23672376

[56.] Li H, Wei YD, Liao FH, Huang Z. Administrative hierarchy and urban land expansion in transitional China, Applied Geography,
(2015)
vol.
177-186.

56, $\quad p$

https://doi.org/10.1016/j.apgeog.2014.11.029

[57.] Guan, D.J., Li, H.F., Inohae, T., Su, W.C., Nagaie, T., Hokao, K.

Modeling urban land use change by the integration of cellular automaton and Markov model. Ecol Model, (2011),222:37613772. https://doi.org/10.1016/j.ecolmodel.2011.09.009

\section{How to Cite This Article}

Rouhani, A., Elmi, M., Assessment of urban land expansion using remote sensing and GIS: A case of Shiraz city, Iran, Brilliant Engineering, 2(2021), 12-19.

https://doi.org/10.36937/ben.2021.002.002 